\title{
Perspective of use of reclaimed lands of humid zone of Ukraine in conditions of climate fluctuations
}

\author{
Yu. Tarariko, \\ Corresponding Member of the National Academy of Sciences of Ukraine, Doctor of Agricultural Sciences \\ R. Saidak, Yu. Soroka, \\ Candidates of Agricultural Sciences \\ Institute of Water Problems and Land Reclamation of the National Academy of Agricultural Sciences
}

The purpose. To determine quantitative parameters and regularities of climatic fluctuations, in particular state of watering of Polissya zone, and to justify directions of development of water managements. Methods. Correlation, cluster and spectral analysises of retrospective databases of agro-meteorological indexes by regions of Ukraine; abstractlogical; comparisons and analogs. Results. It is fixed that for last decades in Ukraine, in particular in Polissya zone, there were essential climate fluctuations. Conditions of humidification of vegetation period have varied from wet and excessively wet to insufficiently wet. Conclusions. The gained results testify to necessity of revising existing strategy and practice of use of reclaimed lands of humid zone into direction of accumulation of moisture reserves during autumn-winter season and implementation of techniques of active regulation of water-air regime of soil.

Key words: climate, hydrothermal conditions, drainage, irrigation.

For significant climate change in the direction of increasing or decreasing rainfall and warming, the importance of agricultural lands in humid regions of Ukraine, including the drainage area. On the one hand this is due to the fact that such changes in the forest-steppe and steppe particularly lead to a reduction of favorable conditions for growing of field crops and increase their yield variability from year to year. On the other hand a decrease hydrothermal coefficient (SCC) zone Polissya [1] contrast to expect positive trends in productivity of agricultural land [2-6].

The purpose of research - to set quantitative parameters and patterns of climate change, including moisture condition Polissya zone and justify prospects of reclaimed land in humid zones example Polissya of Zhytomyr region.

Method. One of the indicators for assessing volohozabezpechennya is potential evaporation. That is, the amount of water that can evaporate from the surface for an unlimited amount of water (equivalent evaporation from water surface). This value is determined by supplies of heat, humidity, wind speed and so on. Therefore, the ratio of evaporation and precipitation can be seen as an indicator teplovolohozabezpechennya natural complex. It creates a picture of the balance of heat and moisture, and also allows you to assess volohozabezpechenist territory:

$$
K_{36}=R / E
$$

where $K_{38}$ - moisturizing factor;

$R$ - precipitation for the year, $\mathrm{mm}$;

$E$ - potential evaporation per year, $\mathrm{mm}$.

Based on this ratio can be calculated and the absolute value of climatic water balance:

$$
K B \bar{B}=R-E
$$

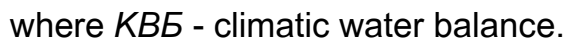

The annual value KBБ underlying the zoning of Ukraine in terms of ensuring hydrothermal resources.

From the statistical characteristics of hydrothermal indicators territory used:

- Arithmetic average calculation and evaluation of the difference of two averages;

- Calculation of the weighted arithmetic mean;

- Calculation of 50, 60, 70, 80 and $90 \%$ level of security;

- Calculation of probability repetition interval values.

To calculate the above statistical variables commonly used in statistics formulas and approaches [8-9].

Results. During the period of 1961-2014 years average annual temperature of air is directed towards growth of 6.3 to $8.6^{\circ} \mathrm{C}$ (Fig. 1), in 54 -year period increased by $2,3^{\circ} \mathrm{C}$ or $0,04^{\circ} \mathrm{C}$ year. The average annual air temperature for the $1991-$ 2014 biennium. $1,2^{\circ} \mathrm{C}$ to exceed the average of $1961-1990$. The most intensive increase of the temperature regime for the period $1991-2014 \mathrm{gg}$. Observed in winter - on $1,5^{\circ} \mathrm{C}$, summer -1.4 and spring - to $1,3^{\circ} \mathrm{C}$, whereas in autumn it grew by only $0,6^{\circ} \mathrm{C}$ (Fig. 2 ). 


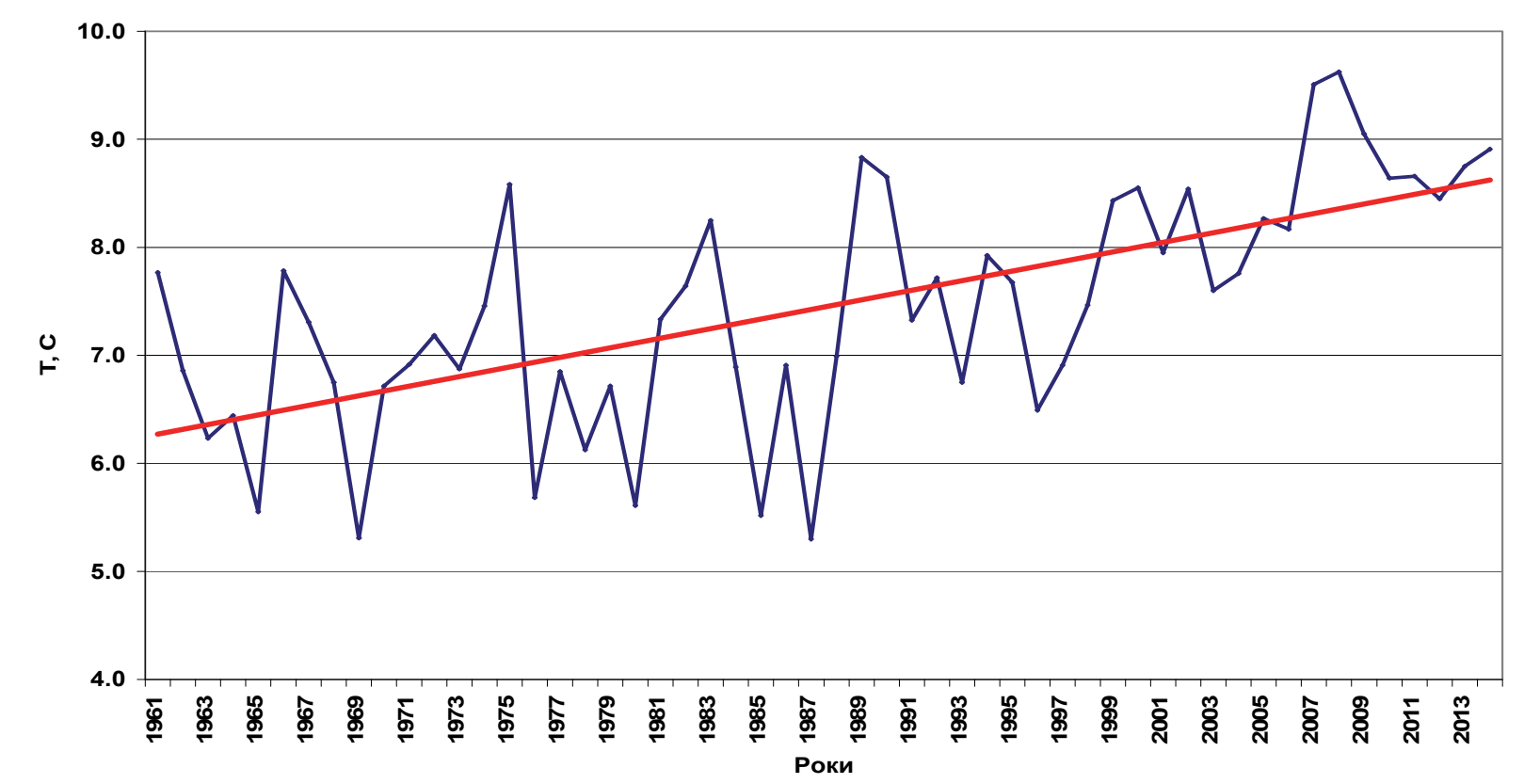

Fig. 1. Dynamics of average annual temperature in Zhytomyr weather station at $1961-2014$ gg., ${ }^{\circ} \mathrm{C}$

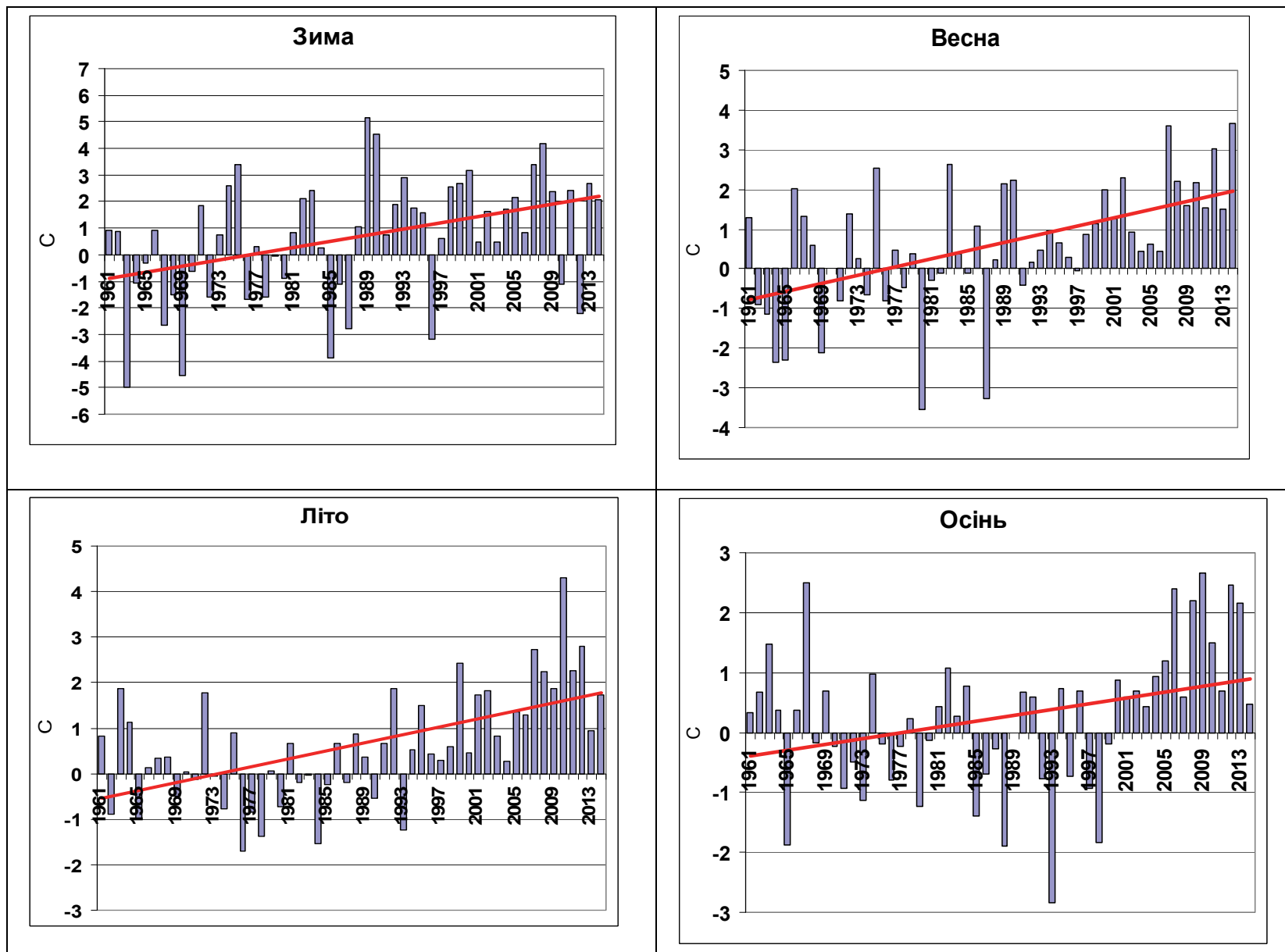

Fig. 2. Dynamics of variations in temperature from normal seasons for $1961-2014$ gg., in Zhytomyr weather station, ${ }^{\circ} \mathrm{C}$

Dynamics of annual precipitation amounts from 1961 to 2014 and directed towards a slight increase from 597 to 621 mm (Fig. 3), or 4\%. In terms of seasons, only in summer rainfall speaker directed downwards (Fig. 4). 


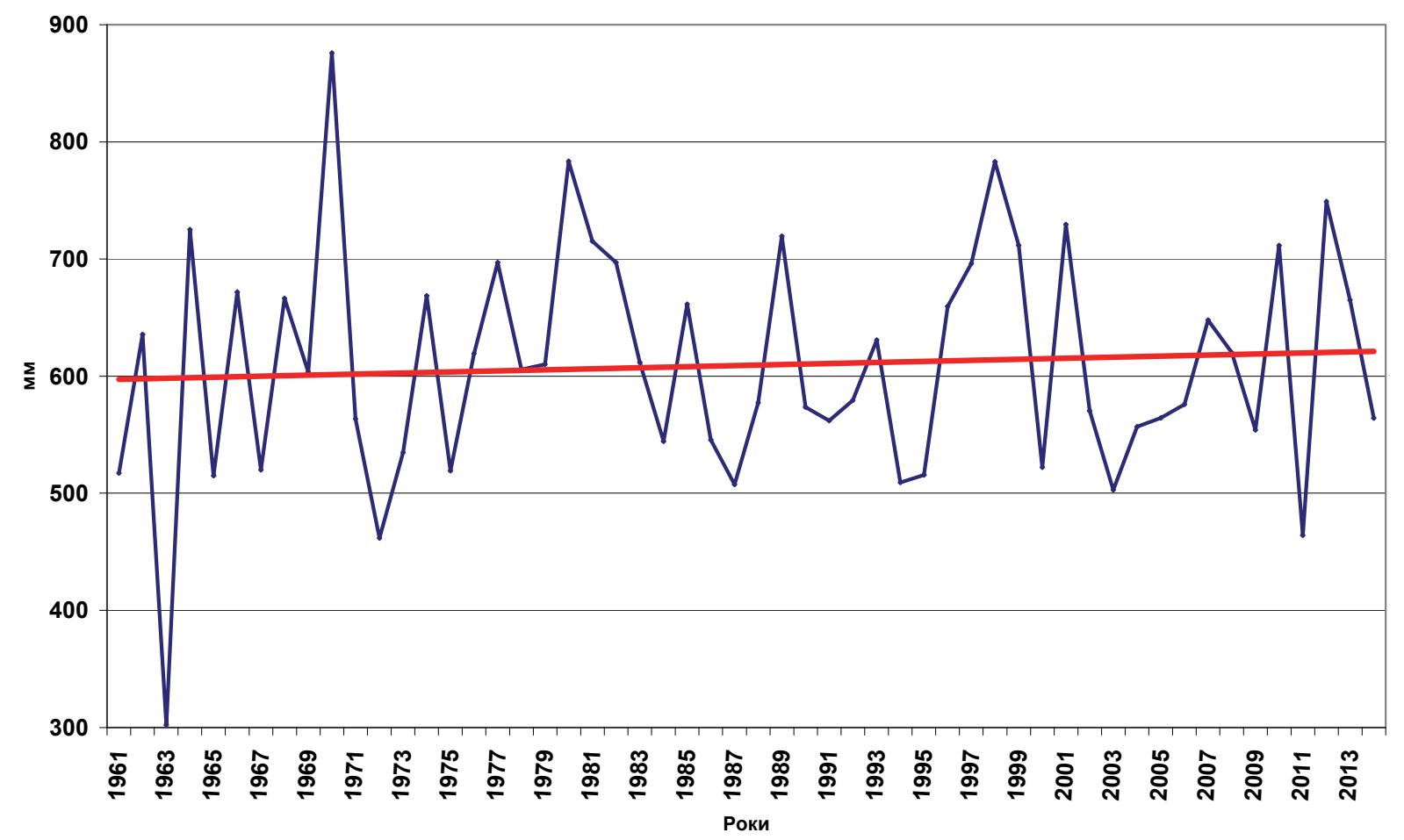

Fig. 3. Dynamics of annual rainfall amounts in Zhytomyr weather station at $1961-2014 \mathrm{~mm}$
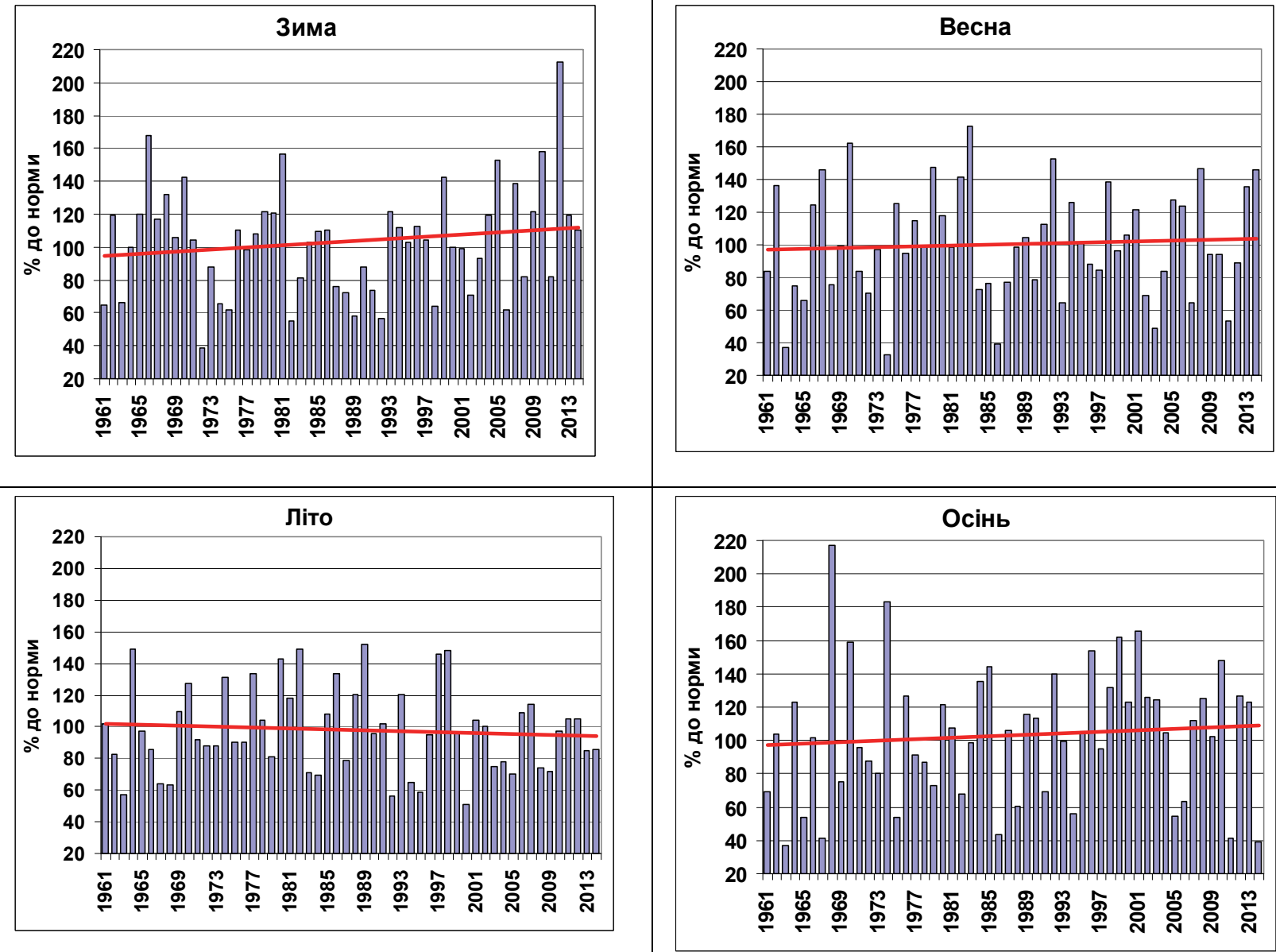

Fig. 4. Dynamics of variations in rainfall seasons from the norm for 1961 - 2014 in Zhytomyr weather station, $\mathrm{mm}$

Assessment of the dynamics of hydrothermal coefficient (SCC) for April - September shows that from 1961 to the end of 80 - ies it was sent to the general trend towards growth from 1.22 to 1.58 , and from 1985 to 2014 - a towards a significant reduction to 1.24 (Fig. 5). That is, the growing season moisture conditions have changed over from wet and moist enough to wet. 


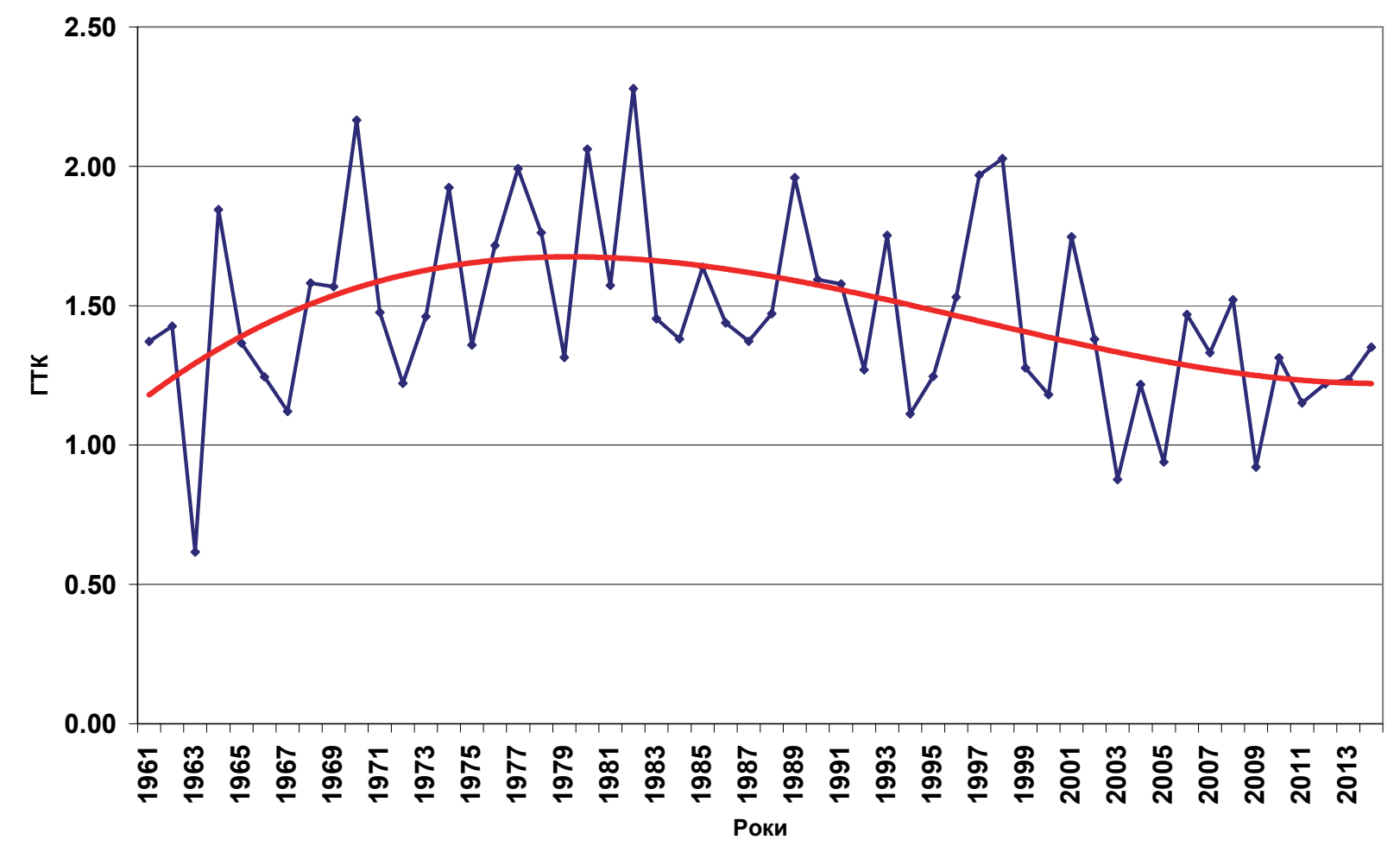

Fig. 5 Dynamics of hydrothermal coefficient April - September Zhytomyr weather station for the 19612014 biennium

In the whole region for the 1961-2014 biennium with a probability of 25\% appear excessively wet conditions of the growing season in 1961-1990. Likelihood of reaching 34\% and over the last 24 years - dropped to 16\% (Table. 1), ie almost twice less marked waterlogged conditions. The wet growing season occurs in $60 \%$ of cases and the frequency of its repetition remains stable. Not enough wet conditions in the growing season during the 1961-1990 biennium. Only observed in 3 percent of cases, and in the 1991-2014 biennium. Likelihood of their recurrence increased to $20 \%$.

\section{The probability of repetition of various shades STC, $\%$}

\begin{tabular}{|l|c|c|c|}
\hline \multirow{2}{*}{\multicolumn{2}{|c|}{ SCC April - September }} & \multicolumn{3}{|c|}{ Periods } \\
\cline { 2 - 4 } & $1961-2014$ years & $1961-1990$ years & $1991-2014$ years \\
\hline$<1,60$ (too wet) & 25 & 34 & 16 \\
\hline $1,21-1,60$ (wet) & 60 & 60 & 60 \\
\hline $0,91-1,20$ (not wet) & 11 & 3 & 20 \\
\hline $0,61-0,90$ (dry) & 4 & 3 & 0 \\
\hline$>0,60$ (very dry) & 0 & 0 & 4 \\
\hline
\end{tabular}

Thus, despite a slight tendency to increase the number of precipitation, moisture conditions of the growing season, resulting in a significant increase in thermal regime as a whole in the region deteriorate. However, with this reduced the need for drainage reclamation activities.

Estimate of annual climatic water balance (KVB) based on observations Zhytomyr weather station also showed the trend deterioration in humid support. Thus, during the 1961-2014 biennium. KVB fell from minus $20 \mathrm{~mm}$ to $60 \mathrm{~mm}$ or 80 $\mathrm{mm}$ (Fig. 6). If the average during 1961-1990. KVB was positive and amounted to about $5 \mathrm{~mm}$, in the 1991-2014 biennium. Its average deficit reached $50 \mathrm{~mm}$.

Also significantly changed and moisture conditions throughout the year. Thus, on average during 1961-1990. Cumulative positive balance since January persisted until the end of July, and in the 1991-2014 biennium. - Until the end of May - June (Fig. 7). That is, the probability of creating conditions moisturizing deficit during the growing season has increased significantly.

At the end of the growing season early crops (July) in the $1991-2014$ biennium. With a probability of $17 \%$ ( $40 \%$ in 1961-1990.) KVB is positive and exceeds $20 \mathrm{~mm}$, and with a probability of $66 \%$ of the deficit may reach 20 to $130 \mathrm{~mm}$. That likelihood of dry conditions increased by $26 \%$, while wetland, on the contrary, decreased by $23 \%$. 


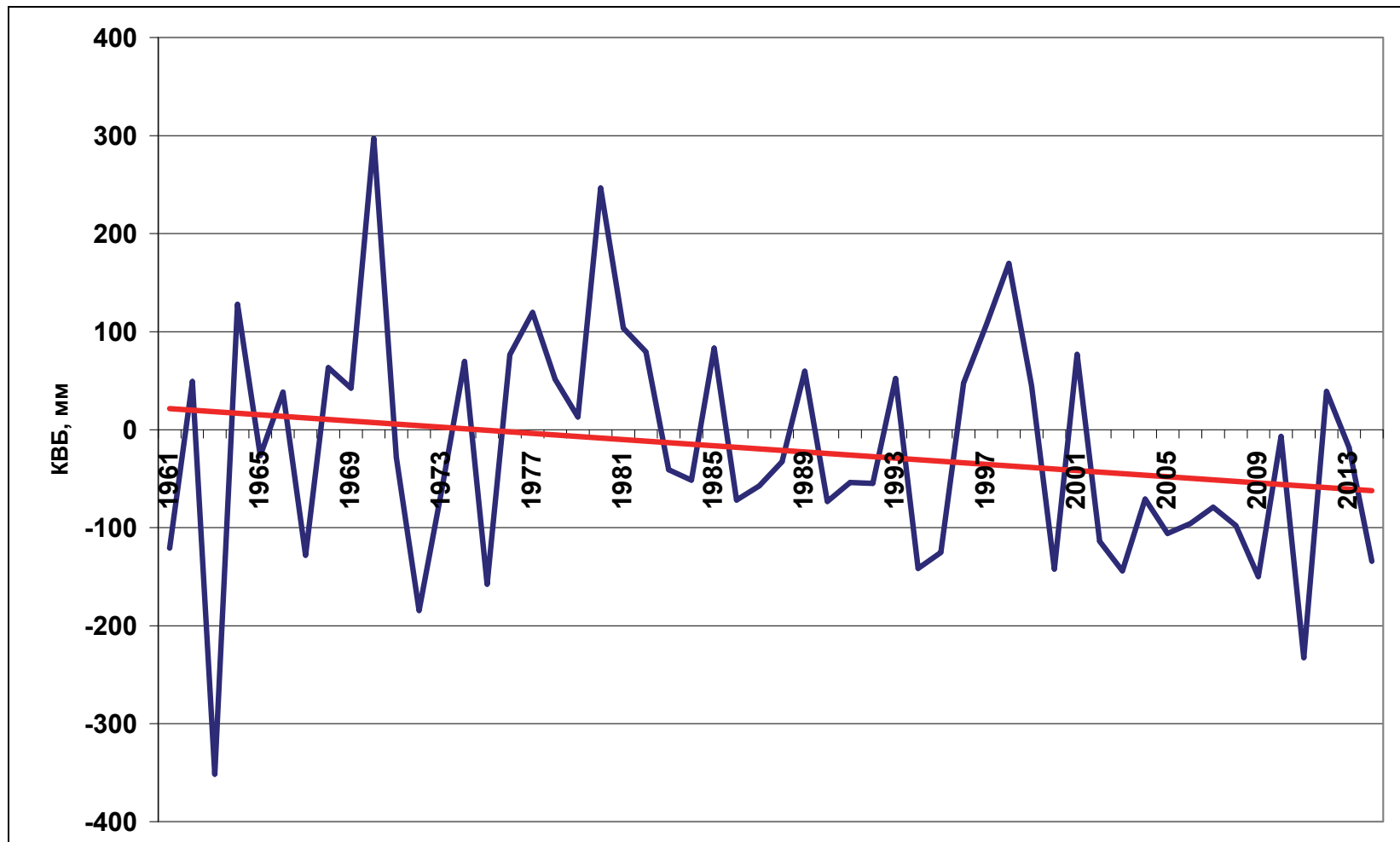

Fig. 6. Dynamics of annual KVB in Zhytomyr weather station for the 1961-2014 biennium.

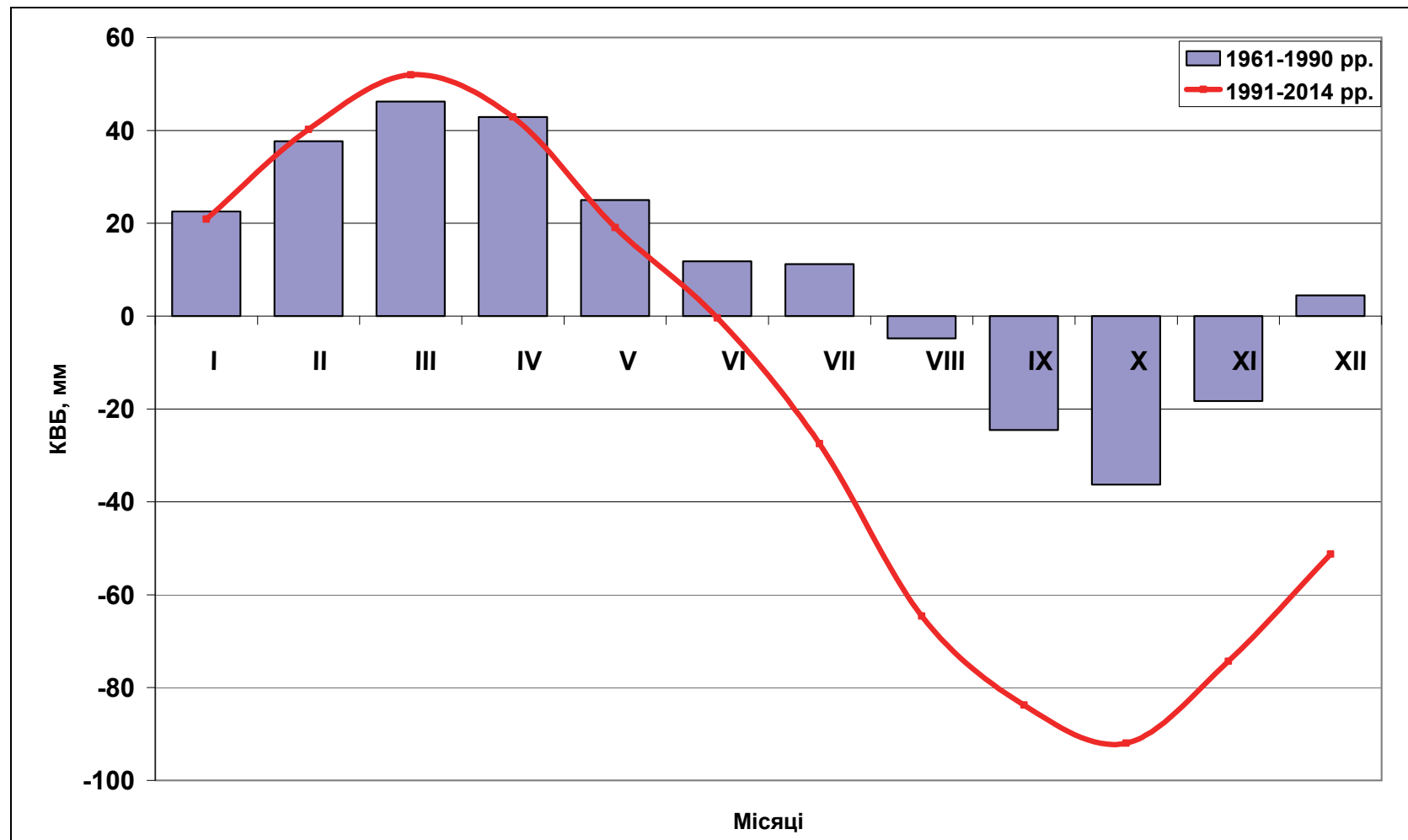

Fig. 7 KVB Dynamics by months, the cumulative in Zhytomyr weather station for 1961-1990 and 19912014 years.

These comparative assessment KVB in regions Ukraine show [10] that area of the country with abundant and sufficient atmospheric moisture compared to 1961 - 1990 rr. For the past 22 years decreased by $10 \%$ (Fig. 8). 


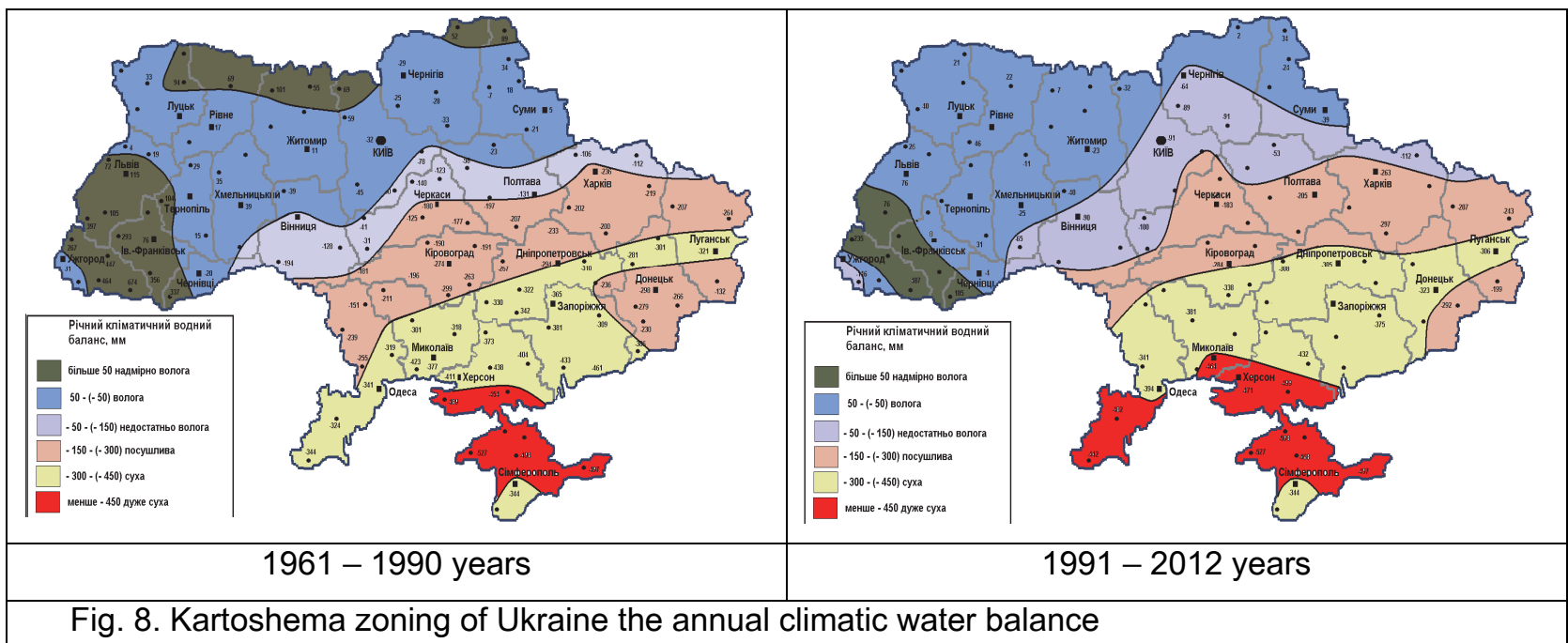

Overly wet areas with annual KVB than $50 \mathrm{~mm}$ were only $66 \%$ of the Transcarpathian, $55 \%$ - Ivano-Frankivsk and $32 \%$ - Lviv regions. At the same time, $3 \%$ of Zhytomyr, $11 \%$ - and $52 \%$ of Zakarpattya - Chernihiv regions assessed as not wet (tab. 2).

2. The relative area of hydrothermal zones to provide areas of Polesie ( $\%$ of total area)

\begin{tabular}{|c|c|c|c|c|c|c|c|c|c|c|c|c|}
\hline \multirow{3}{*}{ Область } & \multicolumn{12}{|c|}{ Zone } \\
\hline & \multicolumn{2}{|c|}{$\begin{array}{c}\text { Excessively } \\
\text { wet, } \\
50^{*}\end{array}$} & \multicolumn{2}{|c|}{$\begin{array}{c}\text { Moisture, 50- } \\
(-50)\end{array}$} & \multicolumn{2}{|c|}{$\begin{array}{l}\text { Insufficient } \\
\text { moisture, } \\
-50-(-150)\end{array}$} & \multicolumn{2}{|c|}{$\begin{array}{l}\text { Rainless, } \\
-150-(300)\end{array}$} & \multicolumn{2}{|c|}{$\begin{array}{c}\text { Dry, } \\
-300-(-450)\end{array}$} & \multicolumn{2}{|c|}{$\begin{array}{l}\text { Very dry, } \\
-450\end{array}$} \\
\hline & $\begin{array}{l}1961- \\
1990\end{array}$ & $\begin{array}{l}1991- \\
2012\end{array}$ & $\begin{array}{l}1961- \\
1990\end{array}$ & $\begin{array}{l}1991- \\
2012\end{array}$ & $\begin{array}{l}1961- \\
1990\end{array}$ & $\begin{array}{l}1991- \\
2012\end{array}$ & $\begin{array}{l}1961- \\
1990\end{array}$ & $\begin{array}{l}1991- \\
2012\end{array}$ & $\begin{array}{l}1961- \\
1990\end{array}$ & $\begin{array}{l}1991- \\
2012\end{array}$ & $\begin{array}{l}1961- \\
1990\end{array}$ & $\begin{array}{l}1991- \\
2012\end{array}$ \\
\hline Volyn & 16 & - & 84 & 100 & - & - & - & - & - & - & - & - \\
\hline Zhytomyr & 28 & - & 72 & 97 & - & 3 & - & - & - & - & - & - \\
\hline Zakarpattya & 83 & 66 & 17 & 23 & - & 11 & - & - & - & - & - & - \\
\hline Ivano-Frankivsk & 92 & 55 & 8 & 45 & - & - & - & - & - & - & - & - \\
\hline Lviv & 79 & 32 & 21 & 68 & - & - & - & - & - & - & - & - \\
\hline Rivne & 42 & - & 58 & 100 & - & - & - & - & - & - & - & - \\
\hline Chernihiv & 10 & - & 90 & 48 & - & 52 & - & - & - & - & - & - \\
\hline
\end{tabular}

* - Annual climatic water balance, $\mathrm{mm}$

So close to the probability of repetition too damp and not wet conditions of the growing season demonstrates the need for reconstruction and modernization of reclamation towards the possibility of a previous accumulation of significant amounts of water resources and their effective use during the growing season through active bilateral regulation of water and air regime of soil or the introduction of irrigation .

Wet zone, which includes the majority of regions Woodlands, given the possibility of forming as excessively and insufficiently moist conditions of the growing season requires bilateral water regime in the area about $7 \mathrm{mln}$. Ha of arable land $(22.4 \%)$. Continuous draining appropriate only to 0.661 million. $\mathrm{Ha}(2.1 \%)$ of arable land in the country, that is, the squares placed in excessively humid area.

\section{Conclusion.}

By reducing annual saving trends KVB can expect a significant deterioration in humid conditions provide a humid zone of Ukraine. In the long term deficit by 2050 annual climatic water balance in the region can reach $70-80 \mathrm{~mm}$. At the end of the spring period KVB 35-year stabilized at zero, and the end of June - August, the deficit will reach $36-64 \mathrm{~mm}$, which corresponds to insufficient wet zone. Under these conditions need drained, even in the early spring period, may disappear. This situation has now require development of new approaches and technologies using agricultural land in the area of Woodlands, where ground water regime largely reduced to discharge excess spring flood. These approaches need to base on increasing water content areas by creating a system of accumulation of water resources and the implementation of technologies optimize moisture conditions in dry periods of the growing season. 


\section{Bibliography}

1. T. Adamenko Agro-climatic zoning of Ukraine with regard to climate change / TI Adamenko. - Kyiv, 2014. - $16 \mathrm{p}$.

2. Saiko VF Agriculture in the context of climate change / VF Saiko // In coll. Scientific Proceedings of the National Scientific Center "Institute of Agriculture UAAS" .- Kyiv, 2009.- P. 3-14.

3. N. Kulbida agrometeorological conditions and productivity of winter wheat in Ukraine Climate Change / MI Kulbida // Abstract candidate. Geography. nauk. Odessa, 2003.-32 p

4. Hodkinson, I.D. Herbivory in global climate change: Direct effects of rising temperature on insect herbivores // Global Change.- 2003.- Volume 8.-P. 1 - 9.

5. Dmytrenko VP Climate change and sustainable development issues Ukraine / VP Dimitrenko // Problems of sustainable development of Ukraine. - Kyiv: BMT, 2001. - P. 371-383.

6. UK Met Office. Impacts of climate change Ukraine. 2010 [electronic resource]. - Access: http://www.climateinfo.org.ua/library/Climate-change-report-Ukraine-eng.pdf

7. Statistics: Training-practical posobye / [M. G. Nazarov et al.]. - Moscow: KnoRus, 2008. - 479 p.

8. Statistics: Theory and Practice in Excel: uchebnoe / VS Lyalin, IG Zverev, N. Nikiforov. - Moscow: Finance and Statistics: Infra-M, 2010. - 446 p.

9. Theory of Statistics / [PG Vashka et al.]. - Kyiv: Lybid, 2001-320 p.

10. YA Tarariko Zoning in Ukraine in terms of availability of hydrothermal resources and the volume of agricultural reclamation / YA Tarariko, RV Saydak, Y. Soroka SV Vitvitskyy // K .: CB "Komprynt" 2015 - 62 p. 